\title{
The Impact of Industrial Revolution 4.0 on Indonesian Export and Welfare: Food and Beverage Case
}

\author{
Iwan Hermawan ${ }^{1 *}$ \\ ${ }^{1}$ Expertise Agency-Secretariat General of the House of Representatives of the Republic of Indonesia \\ ${ }^{*}$ Corresponding author. Email: iwan.hermawan@dpr.go.id
}

\begin{abstract}
The Indonesia's food and beverage sector is one of the most essential sector with huge contribution on GDP, manufacturing exports, and absorbing workforce. Indonesia concerns and makes it as an initial application of industrial revolution 4.0 through especially accelerating export. But whether it would be able to improve the Indonesian export performance and welfare or even make worse off. The delay in adjustments between commitments doing industrial revolution 4.0 and the readiness of resource management skills will be major obstacle. This study aims to analyze the impact of industrial revolution 4.0, especially food and beverage sector, on Indonesian export and welfare. A quantitative approach was applied. GTAP Model was considered appropriate to analyze the impact on Indonesian export, welfare, and also sectoral issue. Main data came from GTAPAgg version 11 and some complementary data was also presented to support research analysis, which sourced from Worldbank, IMF, BPS, and etc. The results indicated that the presence of industrial revolution 4.0 on Indonesian food and beverage sector will improve economic growth, export performance, and also welfare. Moreover, if Indonesian industrial revolution is done by opening trade with ASEAN countries, it would able to boost the result better.
\end{abstract}

Keywords: Food and Beverage Sector, Industry, Export, Welfare, GTAP Model.

\section{INTRODUCTION}

Industrial revolution 4.0 becomes a great momentum and an essential opportunity to accelerate Indonesian growth. It is marked by rapidly developing digital technologies and profoundly change economic, society, and business issues. Based on World Bank data in 2017, Indonesia's manufacturing industry was sixteenth ranking among countries in the world, as sector had contributed more than 20 percent of Gross Domestic Product (GDP). Unfortunately, its contribution tends to decline due to structural economic. On the other hand, the population of productive age is expected increasing by 30 million people by 2030 . Government has to create job fields to reduce unemployment rate and also maintain purchasing power. And industrial revolution 4.0 is expected to increase exports through net exports of 10 percent of GDP in 2030.

The food and beverage sector has the largest role in manufacturing industry. Almost last 2 decades, its performance has shown volatility tends to increase. Food and beverage sector also dominate in employment absorption [1] and export of manufacturing exports.
Ministry of Industry is optimistic that industrial revolution 4.0 will encourage product and export market diversification. When compared to other countries, particularly in ASEAN, Indonesia's food and beverage has large export growth potential because of agricultural resources abundant.

Association of Southeast Asian Nations (ASEAN) region is nearest one with the great economic potential. ASEAN will be the world's fourth largest economy by 2050 and world's third largest labor force of more than 600 million people, behind China and India [2]. Digital integration is harnessing the digital economy to power and accelerate intra-regional trade and growth, and could stimulate GDP uplift of USD1 trillion by 2025 [3]. Based on reference [4] by going digital, Indonesia can unleash the next level of economic growth-to the tune of USD150 billion in annual economic impact by 2025 . Indonesia doesn't want to miss it with going to build Food and Beverages Powerhouses [5][6]. As economic and digital integration accelerates, it becomes increasingly apparent that the Houses will feed the region. 
Will Indonesia benefit from this situation? Given acceleration of development of food and beverages security still requires adjustments, both momentum and its subjects, and regional and national conditions. Some claim the unemployment would increase due to automation, some other said contrary [7]. The final impact also will be reflected in changes in the welfare level. Therefore, this study is to analyze the impact of industrial revolution 4.0 on Indonesian export and welfare, especially in food and beverage.

Actually, research on the impact of industrial revolution 4.0 has started to be done so many. For example, reference [8] dealing with industrial revolution 4.0 from the business and economic perspectives; reference [9] studied about how to sustain and increase competitive advantage of the Russian Federation by catching and implementing industrial revolution 4.0; and reference [10] using strength, weaknesses, opportunity, threat analysis to get an idea of how the impact of industrial revolution 4.0 on Russian Industry.

\section{METHODOLOGY}

\section{Data}

In this research, using secondary data and divide into 2 groups. First for GTAP Model, the data was sourced from GTAPAgg2 (GTAP 9.0) released year 2016 and processed by GEMPack software. The full database contains information on 140 regions and 57 sectors or commodities, then we disaggregated it into 10 regions and 5 sectors. Second for result analysis, those data came from World Bank, International Monetary Fund (IMF), Ministry of Industry of the Republic of Indonesia, and so on.

\section{Analysis Method}

This study uses quantitative approach to answer research objective. The complexity of relationship among food and beverages sector condition, various trade policies in Indonesia and ASEAN are the reason for applying GTAP Model. GTAP Model is comparative static model and presents not changes through time, but differences between different possible states of global economy, a base case and a policy case, at fixed point in time, or with respect to two points in time (base period vs future projection period) [11]. We used standard GTAP Model with perfect competition and constant returns to scale.

GTAP Model represented regional trade level with its instrument. The whole relation that describe the linkages between income and expenditures by any economic agent in the regions (accounting relationship) in GTAP Model

According Ministry of Industry of the Republic of Indonesia, 70 percent of food and beverage small-scale still applied industry 2.0 and 30 percent applied industry was formulated in the equations form. The basic of that regions aggregation is related with this research topic.

\section{Simulation and Closure}

Simulations here carried out to evaluate the impact of government policies related with food and beverage 4.0 in export and welfare. There were 3 simulations, namely simulation 01 presents conditions without policy regarding technology and productivity in food and beverages, simulation 02 presents conditions in which Indonesia seeks to increase its exports followed dynamically by other ASEAN countries, and simulation 03 tries to give an idea if the development of food and beverage 4.0 is only handled by Indonesia itself (isolated).

Changes in technology because of industrial revolution 4.0 here are intended as a variable that can increase the final output indirectly, such as primary factors, intermediate inputs, and added value. And to create more open trading conditions, the Armington elasticity and constant elasticity transformation (CET) parameters are adjusted accordingly increasing 100 percent. CET changes were made to capture food and beverage 4.0 will change more than just production methods. It will shift the points of greatest value added along the value chain.

The closure for three scenarios is almost identical to the standard closure provided by the GTAP Model [12]. There are only two changes made to this standard closure and adopted as in [13], which are (1) swapping the standard numeraire, the global weighted average price for primary factor ( $p$ factwld) with the global weighted average price for capital goods ( $p c d g s w l d$ ) by making the former as endogenous variable and the latter as exogenous variable and (2) swapping private consumption tax $(t p)$ with the change in indirect tax (del_ttaxr) by making the former as endogenous variable and the latter as exogenous variable. The first change is to relax about assumption on the global price of primary factors and second change is to keep indirect tax income unchanged. This closure is maintained in all scenarios.

\section{RESULTS AND ANALYSIS}

Increased global and regional trade has been a key driver of the modernization of all sector in the region [14]. ASEAN's commitment to ASEAN Economic Community (AEC) represents high aspirations for integration and industrial competitiveness. What started as a straightforward push to merely lower formal trade barriers have evolved into vision of dynamic and unified market, one that as a manufacturing base has potential to compete with other [15].

3.0. While medium and large industries have implemented industry 3.0 is 70 percent and 30 percent have implemented industry 2.0. Regarding industrial 
revolution 4.0, Indonesia has strategy, include (1) encouraging productivity in the upstream sector, (2) Indonesia will help small medium enterprises (SMEs) along the value chain to adopt technologies, (3) invest in packaged food products to capture all domestic demand, and (4) increasing exports by utilizing access to agricultural resources and scale of domestic economy.

\section{The Impact Food and Beverage 4.0 on GDP, Balance of Trade, and Trade in Indonesia and Other ASEAN Countries}

Based on Table 1 and 2, in general simulation 02 has better off impact on GDP and balance of trade (BoT) than simulation 01 (default) and 03 (isolated Indonesia). This happens because increasing in use of technology related with industrial revolution 4.0 will stimulate increasing productivity. At the end it will affect the changes in GDP.

Table 1. Impact of Simulation on GDP and Balance of Trade in Indonesia and Other ASEAN Countries

\begin{tabular}{|c|c|c|c|c|c|c|c|}
\hline \multirow[t]{2}{*}{ No. } & \multirow[t]{2}{*}{$\begin{array}{l}\text { Country/ } \\
\text { Region }\end{array}$} & \multicolumn{3}{|c|}{ GDP ( $\triangle$ Percent) } & \multicolumn{3}{|c|}{$\begin{array}{c}\text { Balance of Trade } \\
\text { (USD Million) }\end{array}$} \\
\hline & & $\operatorname{sim} 01$ & $\operatorname{sim} 02$ & $\operatorname{sim} 03$ & $\operatorname{sim} 01$ & $\operatorname{sim} 02$ & $\operatorname{sim} 03$ \\
\hline 1. & Other Countries & 0.01 & 0.03 & 0.01 & 980.83 & 5271.00 & -1531.83 \\
\hline 2. & Indonesia & 2.13 & 4.64 & 2.25 & -1275.56 & 796.98 & 1252.19 \\
\hline 3. & Brunei D. & 0.00 & 5.62 & 0.00 & -2.39 & 254.89 & 1.60 \\
\hline 4. & Singapore & 0.00 & 0.13 & 0.00 & 29.06 & 281.76 & 11.76 \\
\hline 5. & Thailand & 0.00 & 3.56 & 0.01 & 47.00 & 301.11 & 71.37 \\
\hline 6. & Philippines & 0.00 & 3.98 & 0.00 & 39.43 & -3238.63 & 36.69 \\
\hline 7. & Malaysia & -0.02 & 7.40 & -0.02 & 47.89 & 812.10 & 99.87 \\
\hline 8. & Cambodia & 0.00 & 7.12 & 0.00 & -6.45 & -145.25 & -5.82 \\
\hline 9. & Lao & 0.01 & 11.14 & 0.01 & -3.63 & -189.63 & -1.60 \\
\hline 10 & Viet Nam & 0.00 & 7.24 & 0.01 & 143.82 & -4128.43 & 65.78 \\
\hline
\end{tabular}

Source: Processed by RunGTAP.

If it is compared to the impact on GDP by involving ASEAN countries, Indonesia is not the only one who get the biggest positive GDP change. In fact, Malaysia and CMLV (except Myanmar, no data) enjoy also. The acceleration of economic growth becomes compatible with industrial revolution 4.0 momentum. Main reason because they make a lot of infrastructure investments that supported by the influx of foreign direct investment (FDI) and use renewable energy [16]. This condition is very different when industrial revolution 4.0 is only activated in Indonesia. Indeed, this has the biggest positive impact on Indonesia's GDP.

Based on these results, the planning of build Food and Beverages Powerhouse in ASEAN initiated by Indonesia, it would not only have positive impact on Indonesian economic growth but also for other ASEAN countries. Cooperation and competition in food and beverages sector between ASEAN countries through the AEC corridor is still relatively on right track.

The same thing of impact on the BoT, where the Indonesian government has target net export of 10 percent. Even though it did not reach that target, the results were still positive. A positive BoT target is determined not only from food and beverage sector but also other sectors. Therefore, to make it comes true, it also requires an effort to develop industrial revolution 4.0 that targets other sectors, for example textile, garment, electronic, and automotive sector.

Table 2 shows the impact of food and beverages 4.0 on trade in Indonesia and other ASEAN countries. It indicates that government's desire using industrial revolution 4.0 momentum to improve trade performance, especially exports, can be realized. Even some other ASEAN countries are able to enjoy the same thing, such as Brunei Darussalam, Singapore, Thailand, and Malaysia. While the rest actually experienced in exports decline ( sim 02). Unlike isolated Indonesia case ( sim 03), where this condition also indirectly makes other ASEAN countries better off (except Brunei Darussalam), but with magnitude not as big as simulations 01 and 02 . 
Table 2. Impact of Simulation on Trade in Indonesia and Other ASEAN Countries

\begin{tabular}{|c|c|c|c|c|c|c|c|}
\hline \multirow[t]{2}{*}{ No. } & \multirow{2}{*}{$\begin{array}{l}\text { Country/ } \\
\text { Region }\end{array}$} & \multicolumn{3}{|c|}{ Export (Percent) } & \multicolumn{3}{|c|}{ Import (Percent) } \\
\hline & & $\operatorname{sim} 01$ & $\operatorname{sim} 02$ & $\operatorname{sim} 03$ & $\operatorname{sim} 01$ & $\operatorname{sim} 02$ & $\operatorname{sim} 03$ \\
\hline 1. & Other Countries & 0.02 & 0.17 & 0.01 & 0.03 & 0.19 & 0.04 \\
\hline 2. & Indonesia & 2.19 & 7.51 & 4.14 & 1.87 & 6.03 & 2.10 \\
\hline 3. & Brunei D. & 0.00 & 7.43 & -0.02 & 0.01 & 8.07 & 0.14 \\
\hline 4. & Singapore & 0.04 & 0.16 & 0.02 & 0.07 & 0.21 & 0.05 \\
\hline 5. & Thailand & 0.09 & 1.14 & 0.09 & -0.00 & 0.60 & -0.01 \\
\hline 6. & Philippines & 0.09 & -5.64 & 0.11 & 0.04 & 0.39 & 0.05 \\
\hline 7. & Malaysia & 0.29 & 12.16 & 0.56 & 0.35 & 10.50 & 0.63 \\
\hline 8. & Cambodia & 0.08 & -1.68 & 0.11 & 0.38 & -0.03 & 0.41 \\
\hline 9. & Lao & 0.01 & -0.26 & 0.02 & 0.16 & 4.96 & 0.12 \\
\hline 10. & Viet Nam & 0.28 & -2.72 & 0.19 & 0.07 & 1.61 & 0.18 \\
\hline
\end{tabular}

Source: Processed by RunGTAP.

\section{The Impact of Food and Beverage 4.0 on Indonesian and Other ASEAN Countries Welfare}

In Table 3 presents impact of food and beverages 4.0 on welfare. In the GTAP Model, welfare is represented as being derived from allocation of national income between private consumption, government consumption, and savings [12]. This recognizes that households gain benefits from their own current household consumption expenditure. They also benefit from current net national saving, since this increases their future household consumption. Finally, they benefit from the government's provision of public goods and services, as proxies by current government expenditure [17].

Table 3. Impact of Simulation on ASEAN Countries Welfare

\begin{tabular}{|c|l|r|r|r|}
\hline \multirow{2}{*}{ No. } & \multirow{2}{*}{ Country/Region } & \multicolumn{3}{|c|}{ Welfare (USD Million) } \\
\cline { 3 - 5 } & & \multicolumn{1}{c|}{$\operatorname{Sim} 01$} & \multicolumn{1}{c|}{ Sim 02 } & \multicolumn{1}{c|}{ Sim 03 } \\
\hline 1. & Other Countries & $82,77.47$ & $25,187.44$ & $9,968.18$ \\
\hline 2. & Indonesia & $15,825.56$ & $36,286.43$ & $15,848.68$ \\
\hline 3. & Brunei Darussalam & -0.94 & 707.25 & 8.91 \\
\hline 4. & Singapore & 92.52 & 548.91 & 64.23 \\
\hline 5. & Thailand & -178.87 & $11,119.06$ & -148.18 \\
\hline 6. & Philippines & -7.55 & $10,360.70$ & -11.86 \\
\hline 7. & Malaysia & 44.50 & $14,855.14$ & 25.32 \\
\hline 8. & Cambodia & 25.23 & 937.76 & 26.95 \\
\hline 9. & Lao & 2.82 & 921.31 & 3.05 \\
\hline 10. & Viet Nam & -61.73 & $10,895.78$ & 24.46 \\
\hline
\end{tabular}

Source: Processed by RunGTAP.

Indonesia has a superior positive impact on welfare compared to other countries. Even when food and beverages 4.0 involve other ASEAN countries through more open food and beverage trade, the impact is relatively high compared to simulations 01 and 03 .

\section{The Impact Food and Beverage 4.0 on Sectoral in Indonesia}

To elaborate food and beverages 4.0 in detail, the impact is analyzed up to sectoral levels. If Indonesia does not adopt strategy of food and beverage 4.0 ( $\operatorname{sim} 01$ ), 
more sectors will experience a decline in production, includes (a) agriculture and mining and (b) non-food and beverage processing industries. Whereas if Indonesia committed to develop food and beverages 4.0, only production of non-food and beverage processing industries will decline. This occurs because of the priority of the sector is usually accompanied by incentives which ultimately affect production costs. Even the magnitude of production increase very sharply ( $\operatorname{sim} 01$ and sim 02 ) compared to not making industrial revolution in the food and beverage sector.

Furthermore, food and beverages 4.0 has positive impact on all food and beverage exports (sim 01) compared to sim 02 and 03 . The value increases agri-food exports and is higher than food and beverages exports. This confirms that abundant agricultural resources are the main factor in exports driving. When the food and beverages 4.0 involves ASEAN countries ( $\operatorname{sim} 02$ ), the results show better conditions compared to sim 01 and 03.

In addition to production, we can see deep down the impact on labor demand. This section is important for review as well because to confirm many opinions if industrial revolution 4.0 has a negative side in the form of increasing unemployment rate. The food and beverage 4.0 turned out to be able to increase the demand for labor, both skilled labor and unskilled labor, but with involving other ASEAN countries ( $\operatorname{sim} 02$ ) compared to simulation 01 and 02 . This happened due to increased production and exports will encourage an increase in labor demand.

So, why labor demand in agri-food sector decline very sharply? Wages have risen as fast, probably because of large labor pool in rural areas where most unorganized food processing is located. Large variations in wage across province between Java and outside Java and among commodities. The overall trend in labor demand shows no consistent relationship. A deeper analysis of the rural informal sector is needed to disentangle the factors driving employment there.

On the other hand, the farming sector is subject to certain inexorable demographic forces. In almost all regions (except Singapore and Brunei Darussalam) the rural population is declining as people migrate to the cities. This leads to a process of farm consolidation and also reduced labor availability in the countryside which stimulates greater labor productivity. Resultant, demand of labor in agricultural and mining sectors tend to increase ( $\operatorname{sim} 02$ and 03 ).

\section{CONCLUSION AND RECOMMENDATION}

Industrial revolution 4.0 on Indonesian food and beverages sector has an important meaning in accelerating economic growth. Two important things that should be considered are the positive impact of increasing on exports and also welfare. Although it has positive one, decreasing demand for labor in other sectors should be paid attention.

However, all this achievement requires prerequisites that must be fulfilled, namely by cooperating and competition in ASEAN's food and beverage sector. Therefore, the government's target of building the food and beverage powerhouse in ASEAN is a necessity.

\section{REFERENCES}

[1] Okezone.com., "Wow, the food and beverage sector absorb 3.30 million industrial workers" [Wow, sektor makanan dan minuman serap 3,30 juta tenaga kerja industri], November $2^{\text {nd }} 2017$, <https://economy.okezone.com/read/2017/11/02/32 0/1807058/wow-sektor-makanan-dan-minumanserap-3-30-juta-tenaga-kerja-industri>.

[2] Xin En Lee, "ASEAN: What you need to know about the globally important group," April $26^{\text {th }}$ 2018, <https://www.cnbc.com/2018/04/26 /aseanwhat-you-need-to-know-about-the-globallyimportant-group.html>.

[3] Florian Hoppe, Tony May, and Jessie Lin, Advancing towards ASEAN Digital Integration Empowering SMEs to Build ASEAN's Digital Future. Boston, MA: Bain \& Company, Inc., 2018.

[4] Kaushik Das, Michael Gryseels, Priyanka Sudhir, and Khoon Tee Tan, Unlocking Indonesia's Digital Opportunity. Jakarta, ID: McKinsey Indonesia, 2016.

[5] Marc Ingo Wolter, Anke Mönnig, Markus Hummel, Christian Schneemann, Enzo Weber, Gerd Zika, Robert Helmrich, Tobias Maier, and Caroline Neuber-Pohl, C., "Industry 4.0 and the consequences for labour market and economy, Scenario calculations in line with the BIBB-IAB qualifications and occupational field projections," IAB Forschungsbericht Results from the Project Work of IAB 8/2015, 2015.

[6] Kemenperin, "The policy of food and beverage industry sector in the context of implementing the industrial roadmap" [Kebijakan sektor industri makanan dan minuman dalam rangka implementasi roadmap industri], A paper, Ministry of Industry of Republic of Indonesia, 2018.

[7] Kemenperin, Making Indonesia 4.0, A paper, Ministry of Industry of Republic of Indonesia, no year.

[8] Petra Maresova, Ivan Soukal, Libuse Svobodova, Martina Hedvicakova, Ehsan Javanmardi, Ali Selamat, and Onrej Krejcar, "Consequences of 
industry 4.0 in business and economics," Economies Vol. 6 No. 46, pp. 1-14, 2018.

[9] S. Vasin, L. Gamidullaeva, E. Shkarupeta, I. Palatkin, and T. Vasina, "Emerging trends and opportunities for industry 4.0 development in Russia," European Research Studies Journal Vol. XXI No. 3, pp. 63-76, 2018.

[10] Vladislav Genrihovich Frolov, Dmitry Igorevich Kaminchenko, Dmitry Yuryevich Kovylkin, Julia Alexandrovna Popova, and Angelina Alexandrovna Pavlova, "The main economic factors of sustainable manufacturing within the industrial policy concept of industry 4.0," Academy of Strategic Management Journal Vol. 16 No. 2, pp. 1-11, 2017.

[11] Erwin L. Corong, Thomas W. Hertel, Robert A. Mcdougall, Marinos E. Tsigas, and Dominique van der Mensbrugghe, "The standard GTAP Model, version 7," Journal of Global Economic Analysis Vol. 2 No. 1, pp. 1-119, 2017.

[12] Thomas W. Hertal and Marinos E. Tsigas, Structure of GTAP, in Thomas W. Hertal, Ed. Cambridge, UK: Cambridge University Press, 1997, pp. 13-73.

[13] Raymond Mi and Brian Fisher, "The effects of trade openness on food prices and welfare: A Monte Carlo approach," Prepared for the submission for the $20^{\text {th }}$ annual Conference on Global Economic Analysis, June 2017.

[14] BCSD Singapore, PBE, Indonesia BCSD, and Viet Nam BCSD, "Efficient agriculture, stronger economies in ASEAN, private sector perspectives for policy makers," White Paper, BCSD Singapore, PBE, Indonesia BCSD, and Viet Nam BCSD, 2016.

[15] Venkatachalam Anbumozhi and Fukunari Kimura, "Industry 4.0: What does it mean for the circular economy in ASEAN?," in Venkatachalam Anbumozhi and Fukunari Kimura, Eds. Jakarta, ID: Economic Research Institute for ASEAN and East Asia, 2018, pp. 1-35.

[16] OECD, Economic Outlook for Southeast Asia, China and India 2019 towards Smart Urban Transportation. Paris, FR: OECD, 2019.

[17] Kevin J. Hanslow, "A general welfare decomposition for CGE Models," GTAP Technical Paper No. 19, 2000, pp. 1-29. 